\title{
The debris flow hazard in the Lagarelle Creek in the eastern Umbria region, central Italy
}

\author{
P. Conversini ${ }^{1}$, D. Salciarini ${ }^{1}$, G. Felicioni ${ }^{2}$, and A. Boscherini ${ }^{2}$ \\ ${ }^{1}$ Department of Civil and Environmental Engineering, University of Perugia, Italy \\ ${ }^{2}$ Geological Service, Region of Umbria, Italy
}

Received: 21 September 2004 - Revised: 3 March 2005 - Accepted: 9 March 2005 - Published: 18 March 2005

Part of Special Issue "Landslides and debris flows: analysis, monitoring, modeling and hazard"

\begin{abstract}
This paper analyzes the Lagarelle Creek watershed, situated in the Municipality of Vallo di Nera, in the eastern Umbria region, central Italy. In this part of the Region, narrow valleys and very steep slopes characterize the morphology of the Appennine ridge. The presence of strongly-tectonized rocky masses, subdivided by several joint systems, is the main cause for the formation of sorted debris deposits, which accumulate mainly along the topographic convergences. This determines the conditions for possible events of debris flows.

According to previous studies, the basin of the Lagarelle Creek, has been classified as an area prone to a high hazard of debris flows (Regione dell'Umbria - C.N.R. I.R.P.I., 1996). For this reason, systematic studies have been carried out on the whole watershed which, in this first phase, have examined the definition of the geological and morphological features of the zone, by means of the acquisition of cartographies and of field surveys, and the elaboration of the topographical data of the basin, by means of a digital model of the terrain.

Once the potential triggering areas of debris flows were identified, an assessment of the mobilizable volumes possibly involved in a debris flow event was carried out. To perform such an assessment both the geomorphologic method proposed by Hungr (Hungr et al., 1984) and the empirical relations calibrated on debris flow events of the alpine arc were applied. The results obtained were compared with those derived from information supplied by the inhabitants of the small mountain village, who have described in detail the most important events of the last century.
\end{abstract}

\section{Introduction}

Debris flows, because of their high speed of propagation along a torrential stream, constitute one of the most hazardous elements threatening the integrity of inhabited cen-

Correspondence to: P. Conversini

(pconver@unipg.it) tres and infrastructures. Recently, the Geological Service of the Umbria Region, basing on the "Piano stralcio per l'Assetto Idrogeologico (P.A.I.)" (1996), has pointed out 14 zones prone to high risk of debris flows in the eastern Umbria. Systematic studies are being carried out in order to understand the dynamics of these phenomena, directed at assessing the hazard produced by them.

One of the most important aspects in the quantitative evaluations of the hazard connected to the triggering of a debris flow is the assessment of the avalaible material that can be involved in the phenomenon. The tools to carry out this evaluation are multiple: a possible methodology is based on the collection of historical data and on the realization of probabilistic analyses on the series of the occurred events (Brochot et al., 2002). The limit of this approach is that we rarely have accurate information for long periods, regarding the central Apennine area. Another possible methodology concerns the use of empirical and semi-empirical equations. Several authors have proposed this type of formulations, both for the Italian Alps (D'Agostino et al., 1996; Bianco and Franzi, 2000; D'Agostino and Marchi, 2001) and for other regions of the alpine arc (Kronfellner-Kraus, 1985; Rickenmann, 1997). On one hand, their main advantage is that they prove to be ready to use; on the other, the limit is that each equation has been calibrated in areas with specific physical features, not always detectable in other zones. A further methodology is represented by the geomorphologic approaches, based on the evaluation of the existent volumes of loose material along a hydrographical network and available to be mobilized. Among these, the geomorphologic approach proposed by Hungr (Hungr et al., 1984) constitutes a tool to estimate the entity of the debris yields along a torrential stream, classifying its various sections according to their erodibility and therefore to their potential production of mobilizable material.

The aim of this work is to characterize the Lagarelle Creek basin, one of the Umbrian areas susceptible to the debris flow hazard, and to supply a preliminary assessment of the mobilizable volumes that could be involved in a potential 


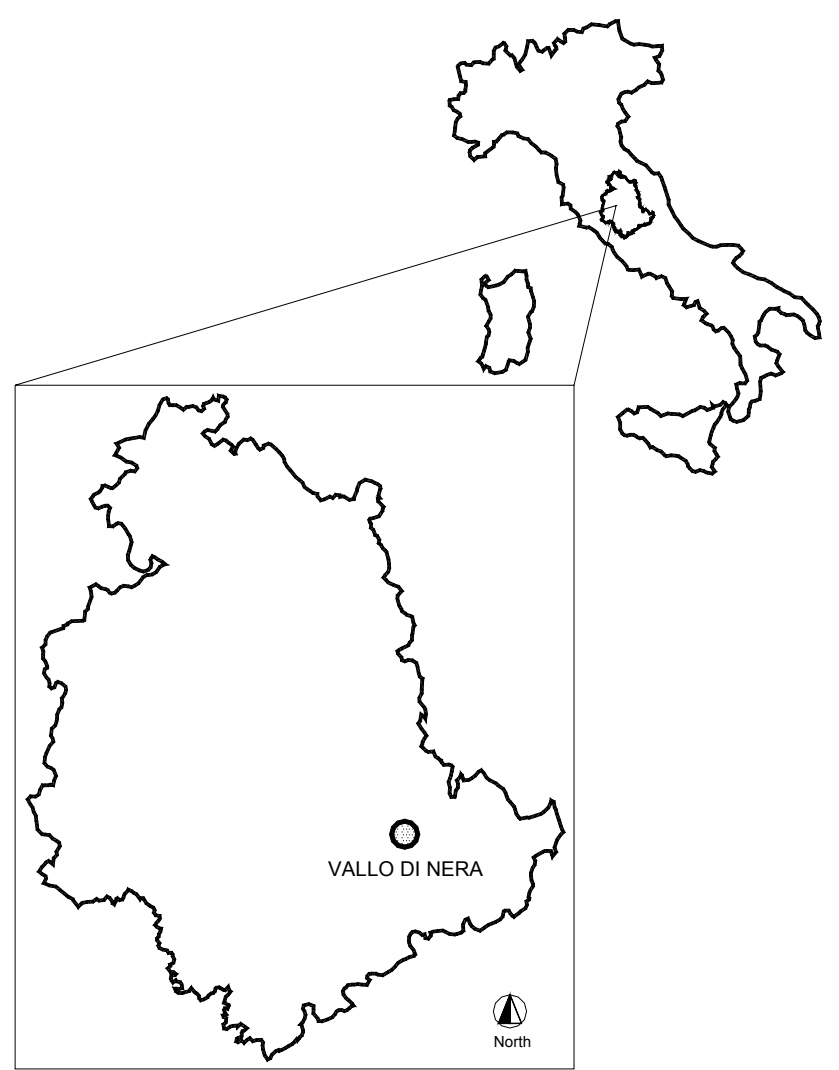

Fig. 1. The study area: Vallo di Nera Municipality in the eastern Umbria, central Italy.

triggering of a debris flow event. Initially, the geological and morphological characteristics of the watershed of the Lagarelle Creek are illustrated. Then, basing on information gathered in the study area from eyewitnesses, two significant events of debris flow are described, which occurred in the last century. To end, both the geomorphologic approach proposed by Hungr and the empirical models, as provided by various authors (D'Agostino et al., 1996; D'Agostino and Marchi, 2001), are applied in order to evaluate the debris flow volumes. The predictions supplied by such methods were compared with the historical data.

\section{Description of the study area}

\subsection{Geological setting}

The study area comprises the watershed of the Lagarelle Creek, with basin-outlet at the Piedipaterno village, in the Vallo di Nera Municipality. This Municipality is located in the in the eastern part of the Umbria region, central Italy (Fig. 1). The stream begins at the Mount Galenne, at an elevation of $1060 \mathrm{~m}$, and drains in the Nera River at $313 \mathrm{~m}$ above the sea level, for a total length of $2400 \mathrm{~m}$. The basin extends for approximately $2.4 \mathrm{~km}^{2}$ and is localized on the right hydrographical side of the Nera River, the main watercourse of the eastern Umbria region (Fig. 2).

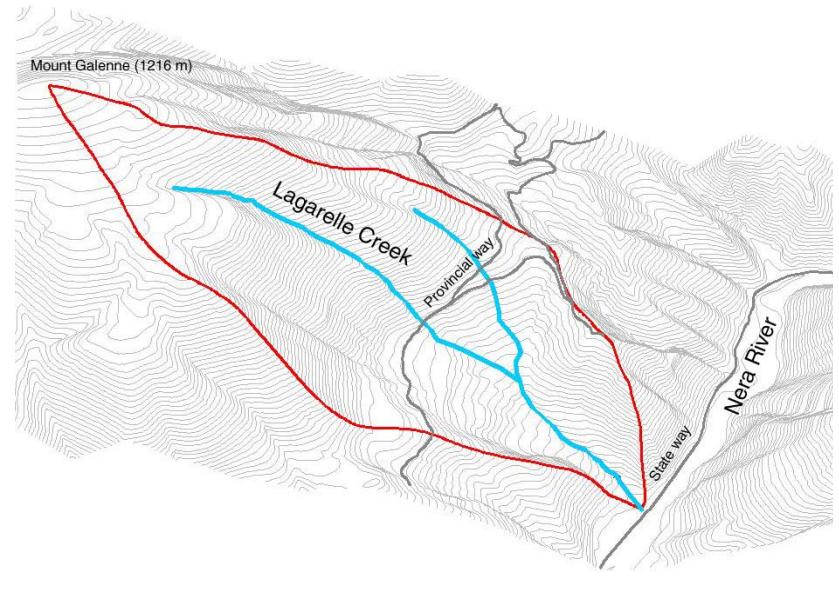

Fig. 2. The Lagarelle hydrographical watershed.

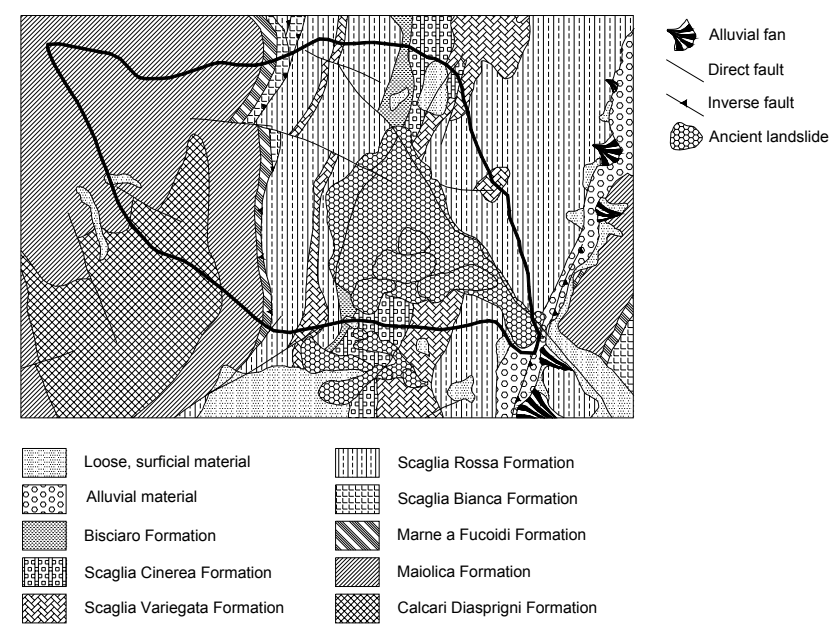

Fig. 3. Geological map of the study area (after the original Carta Geologica dellUmbria scala 1:10 000, sez. Vallo di Nera n. 336030).

In the upper part of the Lagarelle Creek watershed, over $650 \mathrm{~m}$ above the sea level, formations of the UmbroMarchigiana Series crop out in overturned succession, comprised between the Calcari Diasprigni and the Scaglia Rossa Formations, dipping to the west and with an average slope of approximately $30^{\circ}$ : the formations are mainly calcareous, highly jointed and permeable. In the lower part of the basin, beneath the afore-mentioned elevation, crop out the formations comprised between the Bisciaro and the Scaglia Rossa. The latter presents folds along an N-S axis and an inclination of the axis ranging from $30^{\circ}$ to $90^{\circ}$ : the outcropping formations, of limestone, limestone-marly and marly material, erode easily, with medium to low permeability. Recent alluvial and landslide deposits cover the bedrock, at lower elevation, with variable thickness (Fig. 3). 


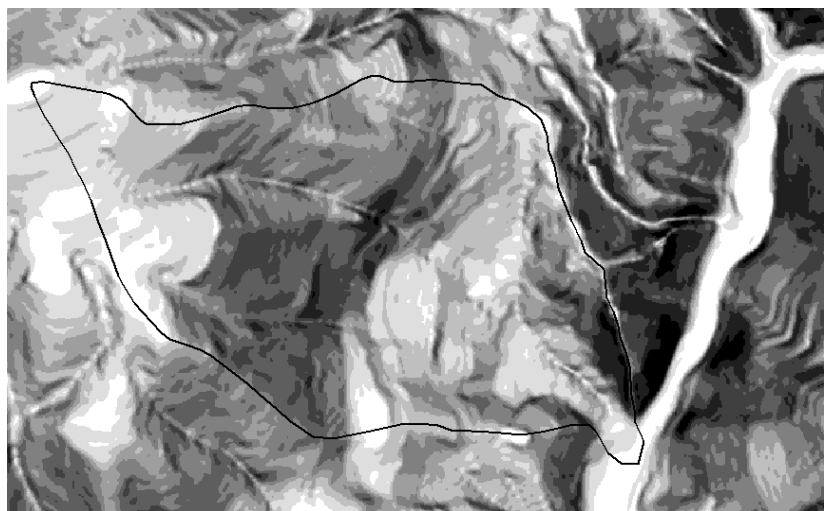

$$
\begin{aligned}
& \text { <UALUE> } \\
& 0-7.5 \\
& \square 7.5-14 \\
& \square 14-20 \\
& \square 20-25.5 \\
& 25.5-30.5 \\
& \text { - } 30.5 \text { - } 35 \\
& \text { - } 35-39.5 \\
& \text { - } 39.5-46.0 \\
& \text { - } 46.0-64
\end{aligned}
$$

Fig. 4. Range of slope angles in the study area.

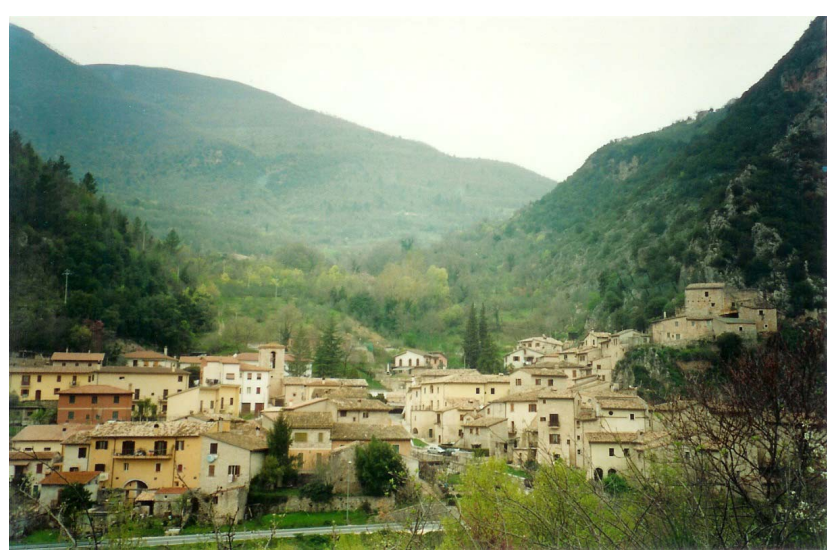

Fig. 5. Piedipaterno village, built on the Lagarelle creek alluvial fan.

2.2 Morphological characteristic and susceptibility to landslides

Slopes exceeding $25^{\circ}$ characterize the general morphology, in the upper part of the basin and in the mountainside on the left hydrographical side; even nearly vertical cliffs are found. In the remaining parts of the basin the slopes are gentler, with average values of approximately $17^{\circ}$, with the exception of local situations, due to landslide escarpments, where the steepness can significantly increase (Fig. 4). The waterdrainage density is medium-low, conditioned by the high degree of fractures and the lithological nature of the bedrock. A pronounced morphological element is the alluvial fan located at the outlet of the Lagarelle Creek basin, where the recent part of Piedipaterno village is built (Fig. 5).

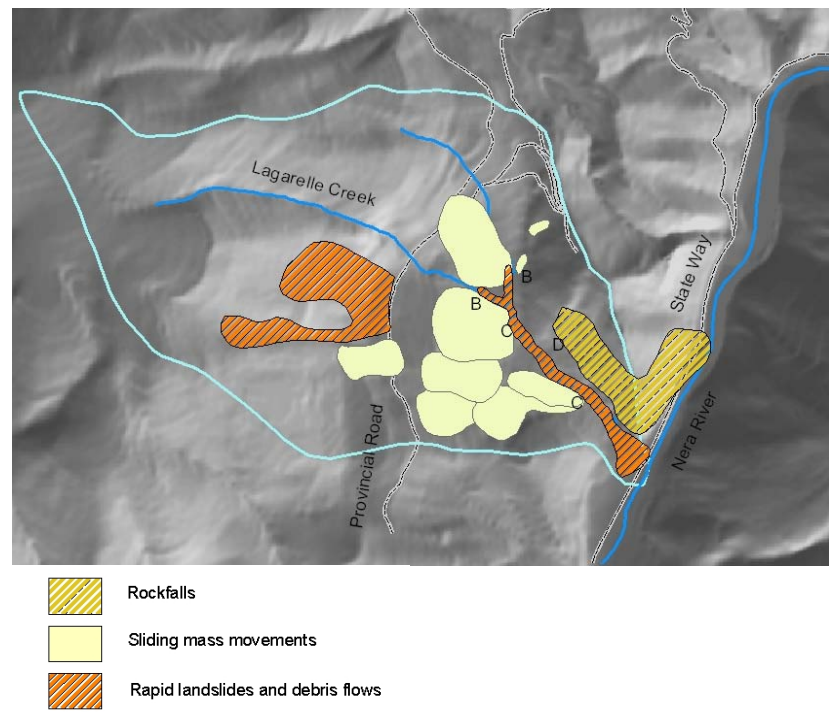

Fig. 6. Shaded relief map and landslide inventory (after the original map produced with the "Piano stralcio per l'Assetto Idrogeologico", 1996).

The multi-temporal analysis of several landslide movements allowed to identify, within the basin, 10 areas subject to either active or dormant instability phenomena, involving rotational and planar sliding, rockfalls and debris flows, as shown in the landslide inventory map produced by the C.N.R. of Perugia (Regione dell'Umbria - C.N.R. I.R.P.I., 1996) (Fig. 6). Generally, in this area, the sliding are deep and wide; the old landslides that can be found in the middle and lower portion of the basin provide interesting examples. Rock falls of varied dimension interest the rocky walls of the left hydrographical side of the Lagarelle Creek, above Piedipaterno: some boulders have hit the old houses next to the slope. The potential triggering zones of debris flows are located in the area that covers the terminal part of the main stream of the Lagarelle Creek, up to the Nera River, and above the Provincial Way "S.P. Meggianese" (Fig. 6).

\section{Debris flows in the Lagarelle Creek}

The historical data referring to debris flows that took place in the study area and, more in general, in the Apennine, are very scarce. No monitoring system is available in the study area and debris flow events are not mentioned by ancient chronicle, due to their being circumscribed phenomena causing just material damage. Therefore, in the present work we refer to the direct memories of the inhabitants of Piedipaterno, regarding the events occurred in the last century. Several inhabitants and members of "Comunanza Agraria" were interviewed; "Comunanza Agraria" being the Committee which has been managing the hillslope since the very beginning of the century. Though not having any photographical or chronicle documentation, the witnesses' fully detailed reports tally. The most important events were reported to have occurred in 1945 and 1965. 


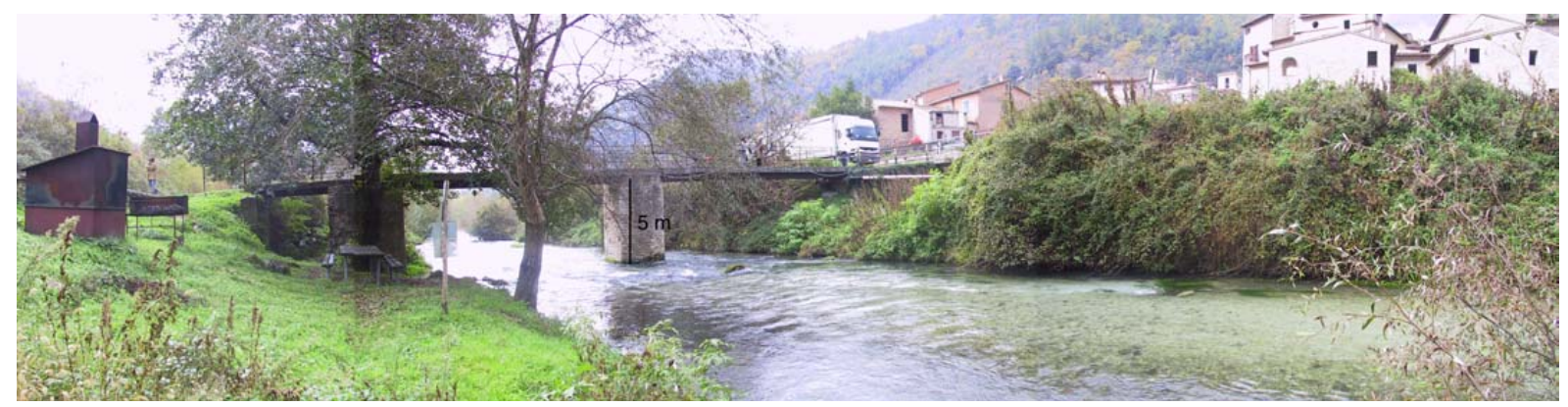

Fig. 7. Cross-section of the Nera River, near the Piedipaterno village.

\subsection{The 1945 event}

In the early afternoon of 6 September 1945, heavy precipitations began, that lasted for few hours. The inhabitants remember, all of a sudden, loud rumbles coming from the upstream zone of Piedipaterno. Immediately after, a flood wave arrived, bringing along considerable amounts of debris material of variable sorting, including rocky blocks of at least 2-3 $\mathrm{m}^{3}$. After the first wave, four other ones followed with intervals of several minutes between each other. The clastic material crossed the town and reached the bed of the Nera River that, in a short time, got obstructed. The successive build-up of sediment raised the debris deposit to the height of the bridge that still connects the two banks, completely obstructing the cross section of the river (Fig. 7). The River Nera's water level rose more than $1 \mathrm{~m}$ above the bridge, invading and causing serious damage to two mills situated approximately $200 \mathrm{~m}$ upstream, to the Spoleto-Norcia railroad that ran along the side of the river, and to a little church in the neighbourhood. The waters of the river eroded in a short time the obstruction provoked by detritus of the Lagarelle Creek, thus generating a wave that flooded all the lands downstream, with serious consequences to the local agricultural economy.

Considering the section of the Nera River, even with the modest modifications pointed out by the inhabitants (for example the different route of the present S.S. 209), and the material released along the section of the creek within the town, the debris caused by the event of 6 September 1945 can be estimated at a minimum of $1800-2000 \mathrm{~m}^{3}$.

\subsection{The 1965 event}

The second important event in terms of the amount of transported material occurred in September 1965. The type of triggering event and the propagation of the debris flows was almost identical to those of the 1945 event. The most striking image still vivid in the memories of the inhabitants refers to the dimensions of several stone blocks pushed ahead together with the flowing mass, with estimated volumes of $2-3 \mathrm{~m}^{3}$.

Some of these blocks stopped at the beginning of the Piedipaterno fan, others along the section that crosses the town, others reached the riverbed of the River Nera. The debris flow partially obstructed the riverbed, although much of it stopped at the beginning of the concrete box made for the
S.S. 209 Valnerina route, outside the town of Piedipaterno. The entity of the debris yield was, by all accounts, smaller than that of the 1945 event: the evaluation, elaborated on the basis of punctual references, would make a cubature of 800$1000 \mathrm{~m}^{3}$ acceptable.

After this second event, eight check-dams were built by the local administration, localized in the lower part of the Lagarelle Creek. Furthermore, in the ending sector of the creek, which crosses the village, the stream was embedded in a concrete channel.

\section{Methods for magnitude assessment}

\subsection{The geomorphic approach by Hungr}

The geomorphic method proposed by Hungr (Hungr et al., 1984) offers a standardized procedure for the evaluation of the available volumes of material along the banks and on the riverbed of a channel under examination. The procedure has been calibrated on the British Columbia debris flows and this work constitutes an attempt to apply the same methodology to the Apennine zones.

The total volume of debris material, of variable sorting, that can be transported downstream during the course of one single event, independently of the number of waves that constitute the debris flow, is called "magnitude of the event". It depends both on the dimensions of the debris source area and on the predisposition of this area to be mobilized in extreme rainfall conditions (Hungr et al., 1984). This amount is commonly called "total mobilizable debris volume", indicated with $V$ and measured in $\mathrm{m}^{3}$.

The total mobilizable debris volume can be evaluated considering the length $L$ of the channel, its width $B$ and its erodibility coefficient $e$. The width of the channel can be directly measured or expressed as square root of the drainage area $A$. Dividing the stream into $n$ sectors having a homogenous erodibility (that is, with homogeneous capability of debris material production), the total volume is therefore calculated as:

$V=\sum_{i=1}^{n} \sqrt{A_{i}} L_{i} \cdot e_{i}$ 
Table 1. Channel debris yield rate for typical stream channels (after Hungr et al., 1984).

\begin{tabular}{|c|c|c|c|c|c|}
\hline $\begin{array}{l}\text { Channel } \\
\text { type }\end{array}$ & Gradient $\left(^{\circ}\right)$ & Bed material & Side slopes & Stability condition & $\begin{array}{l}\text { Channel debris yield } \\
\text { rate }\left(\mathrm{m}^{3} / \mathrm{m}\right)\end{array}$ \\
\hline A & $20-35$ & Bedrock & Nonerodible & $\begin{array}{l}\text { Stable, practically bare of } \\
\text { soil cover }\end{array}$ & $0-5$ \\
\hline $\mathrm{B}$ & $10-20$ & $\begin{array}{l}\text { Thin debris or loose soil } \\
\text { over bedrock }\end{array}$ & Nonerodible & Stable & $5-10$ \\
\hline $\mathrm{C}$ & $10-20$ & Deep talus or moraine & Less than $5 \mathrm{~m}$ high & Stable & $10-15$ \\
\hline $\mathrm{D}$ & $10-20$ & Deep talus or moraine & Talus, over $5 \mathrm{~m}$ high & Side slopes at repose & $15-30$ \\
\hline $\mathrm{E}$ & $10-20$ & Deep talus or moraine & Talus, over $20 \mathrm{~m}$ high & $\begin{array}{l}\text { Side slope potentially un- } \\
\text { stable (landslide area) }\end{array}$ & $\begin{array}{l}\text { Up to } 200 \text { (consider as } \\
\text { point source) }\end{array}$ \\
\hline
\end{tabular}

where $L_{i}$ represents the length of each sectors in meters, $e_{i}$ the "channel erodibility coefficient" (measured in $\mathrm{m}^{3} /(\mathrm{m} \mathrm{km})$ ), and $A_{i}$ the area of the drainage source (measured in $\mathrm{km}^{2}$ ).

The relationship between the erodibility coefficient and the channel debris yield rate depends upon drainage area size and shape. For drainage basins approximable to elongated rectangles of about $2 \mathrm{~km}^{2}$, the two parameters are nearly equal. Therefore, considering watersheds with areas between 1 and $3 \mathrm{~km}^{2}$ the total volume is calculated as:

$V=\sum_{i=1}^{n} L_{i} \cdot e_{i}$,

where $e_{i}$ represents the "channel debris yield rate" (measured in $\mathrm{m}^{3} / \mathrm{m}$ ). Such a rate is obtained empirically, according with the channel type, using the classification proposed by Hungr (Table 1).

Within the study watershed, the zone susceptible to debris flow hazard is located in the terminal part of the Lagarelle Creek, including a short tract of its right-hand tributary. The total length of the sections where debris flow events may occur is about $1110 \mathrm{~m}$. Along the bed of both the channels, loose alluvial clastic material is found, with variable thickness of up to $20 \mathrm{~m}$ in the terminal part of the main stream, at the confluence with the widest valley of the River Nera (Comune di Vallo di Nera, 1997²). Clastic material rests on bedrock constituted by limestone, marly-limestone, and secondary marls. Along the banks, which can reach heights of $10-15 \mathrm{~m}$, clastic heterogeneous material can still be found, with varied density. They constitute important localized sources of debris material.

To examine the principal morphometric characteristics of the basin and the watercourse, a digital elevation model (D.E.M.) of the area was generated. Starting from cartography with scale 1:10000, a D.E.M. with squared cells $(5 \mathrm{~m} \times 5 \mathrm{~m})$ permitted an easy evaluation of the average slope of the basin, the average slope of the streams, and the watershed extension. These kinds of elaborations have been al-

\footnotetext{
${ }^{1}$ Comune di Vallo di Nera: Relazione geologico-tecnica per interventi di ricostruzione a seguito del terremoto 1997, unpublished document (in Italian), 1997.
}

ways compared and discussed with the results of field surveys.

The application of the geomorphic approach by Hungr to the Lagarelle Creek watershed has been developed according to the following steps:

1. recognition of the homogenous tracts of the channel, in terms of riverbed average slope, banks stability conditions, and material formed along the channel bed and sides;

2. measuring of the length of the homogenous tracts of channel;

3. allocation of a value of the unitary sediment contribution based on the categories shown in Table 1. From surveys carried out in the study area, the total extension of the creek where debris flows may occur was subdivided into 5 tracts. The first one begins at an altitude of $505 \mathrm{~m}$ and extends for a length of $140 \mathrm{~m}$, along which the not very dense clastic deposit, of variable sorting, emerges with continuity. In this tract, the torrential stream presents average slopes of $14^{\circ}$; the banks have reduced heights if compared with those of the zone downstream, with maximum values of $2 \mathrm{~m}$, and the inclinations are always below $25^{\circ}$. They are covered with dense shrubby vegetation and there is no evidence of instability processes. Therefore, this tract (tract 1) falls into the class of debris yield B of Table 1. Proceeding downstream, for about $17 \mathrm{~m}$, eterometric clastic material of variable density is still found. The bed of the creek has average slopes of $15^{\circ}$, while the height of the banks increases until a maximum of $5 \mathrm{~m}$, with slope of about $25^{\circ}$. Local processes of instability interest the upper part of these banks (Fig. 8). This tract (tract 2) falls into the type $\mathrm{C}$ category of debris yield. Coming down again for a tract of $200 \mathrm{~m}$, the lithology is not modified while the level of the creek is lowered, reaching slopes of $18^{\circ}$. The banks reach heights of over $10 \mathrm{~m}$, with emphasized inclinations, in some points close to the vertical. There are marked and developed instability phenomena of the banks, mainly correlated with the erosive processes at the foot (Fig. 9). This tract (tract 3) 
Table 2. Results of the application of geomorphologic approach.

\begin{tabular}{ccccc}
\hline $\begin{array}{c}\text { Sector of } \\
\text { channel }\end{array}$ & Channel type & $\begin{array}{c}\text { Length of the } \\
\text { sector }(\mathrm{m})\end{array}$ & $\begin{array}{c}\text { Channel debris } \\
\text { yield rate }\left(\mathrm{m}^{3} / \mathrm{m}\right)\end{array}$ & $\begin{array}{c}\text { Debris volume } \\
\left(\mathrm{m}^{3}\right)\end{array}$ \\
\hline 1 & B & 140 & 5 & 700 \\
$1 \mathrm{~A}$ & $\mathrm{~B}$ & 160 & 5 & 800 \\
2 & $\mathrm{C}$ & 170 & 10 & 1700 \\
3 & $\mathrm{D}$ & 200 & 15 & 3000 \\
4 & $\mathrm{C}$ & 220 & 10 & 2200 \\
5 & $\mathrm{~B}$ & 200 & 0 & 0 \\
\hline
\end{tabular}

Table 3. Geolithologic index (after D’Agostino et al., 1996).

\begin{tabular}{lc}
\hline Lithologic class & Points \\
\hline Alluvial and layered morainic covering & 5 \\
Metamorphic rocks & 4 \\
Terrigenous rocks: marls & 3 \\
Degraded lavic rocks, basaltic, breccias & 2 \\
Calcareous rocks & 1 \\
Porphyritic, granitic rock, diorites & 0 \\
\hline
\end{tabular}

falls into class D of Table 1 . In the successive $220 \mathrm{~m}$ long tract, the slope decreases to $15^{\circ}$ and the banks return to heights below $10 \mathrm{~m}$; nevertheless there are still present localized instability processes, traceable to the erosion caused by the waters of the creek, and this tract (tract 4) again falls into the category of debris yield of type C. Finally, the last part of the creek, which extends for $200 \mathrm{~m}$, crosses the town. After the recorded debris flow event in 1965, this sector was channelled in a reinforced concrete work; therefore the debris yield is assumed null (tract 5). As for the right-hand tributary of the Lagarelle Creek, the tract (tract 1a), which is prone to debris flow risk, is approximately 160 -m length. Its lithological-morphological characteristics are identical to those of the first tract of the main stream and for this it falls into the B class of Table 1.

The data and the results of the proposed classification are summarized in Table 2; the subdivision of the Lagarelle Creek into homogeneous sectors is shown in Fig. 10. The debris volumes for unity of length lead to an evaluation of the accumulated volume equal to $8400 \mathrm{~m}^{3}$.

\subsection{Empirical formulations}

Another method for assessing the materials involved in a potential debris flow is constituted by the use of empirical formulations (Takei, 1984; Bottino and Crivellari, 1996; Marchi and Tecca, 1996). In this work we consider those provided by D'Agostino et al. (1996) and D'Agostino and Marchi (2001), based on a data set in which the presence of basins of limited extension prevails (approximately $75 \%$ of the basins in

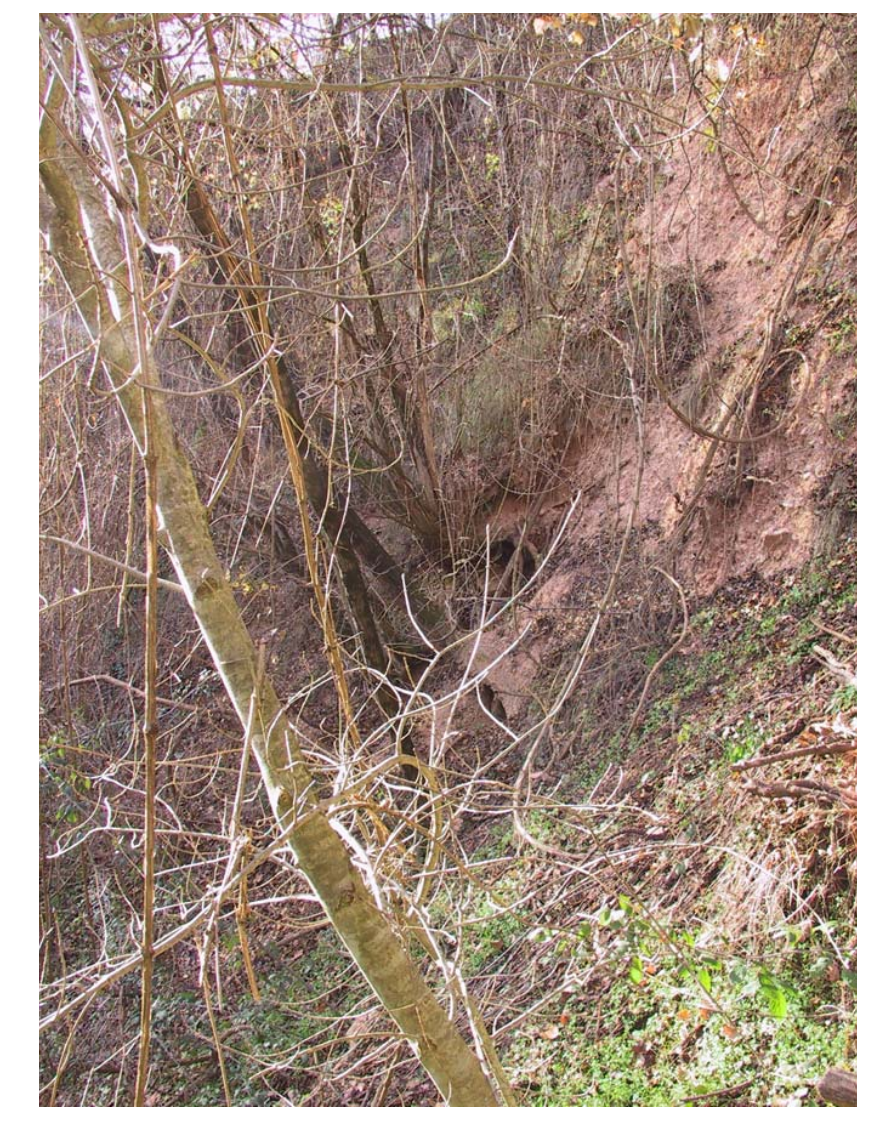

Fig. 8. Banks instabilities along the channel (tract 2).

the data set of the mentioned works are smaller than $5 \mathrm{~km}^{2}$ ). In both cases the elaboration was carried out applying, to the available historical recordings, regression techniques for the minimization of an error function. Such relations supply the estimation of the volumes expressing the magnitude of the event as a function of morphometric parameters and geologic characteristics of the basins. The calibration of the empirical relations by D'Agostino et al. (1996) is based on 62 happened events of debris flow in the province of Trento and leads to the following expression:

$V=45 \cdot A^{0.9} \cdot I_{C}^{1.5} \cdot I G$ 


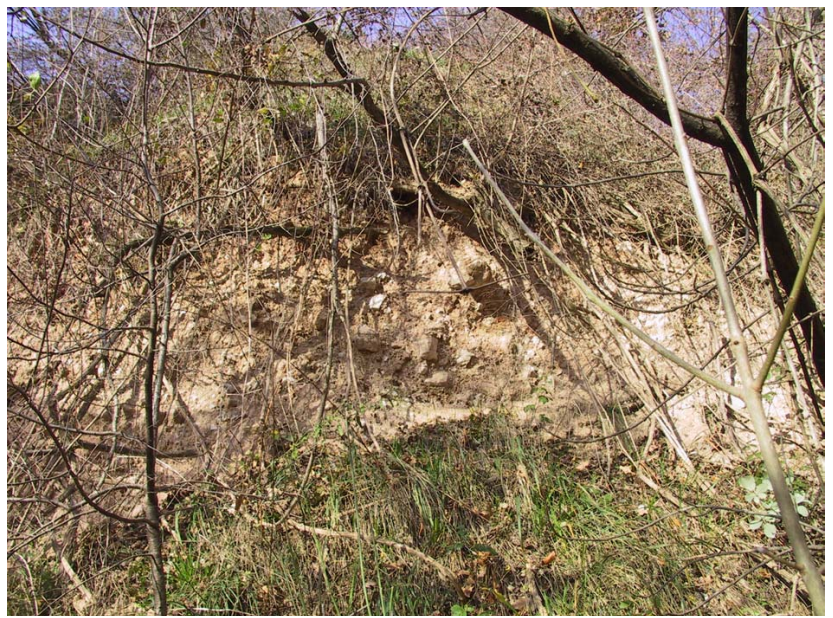

Fig. 9. Banks instabilities along the channel (tract 3). Sub-vertical banks with instabilities related to erosive processes are evident.

where $V$, represents the mobilizable volume in $\mathrm{m}^{3}, A$ the area of the study watershed in $\mathrm{km}^{2}, I_{C}$ the average slope of the stream with percentage value, and $I G$ the geolithologic index (Table 3).

The relation provided by D'Agostino and Marchi (2001) considers 84 historical recordings, regarding a more extended geographic area that includes also the province of Bolzano. It is expressed as:

$V=70 \cdot A \cdot I_{C}^{1.28} \cdot I G$,

where $V$, again, is the estimated volume in $\mathrm{m}^{3}, A$ is the area of the study watershed in $\mathrm{km}^{2}, I_{C}$ is the average slope of the stream with percentage value, and $I G$ is the geolithologic index (Table 3).

To apply the Eqs. (1) and (2) to the drainage basin of the Lagarelle Creek, we assume an extension of the watershed equal to $2.4 \mathrm{~km}^{2}$ and an average slope of the river channel equal to $32 \%$.

The assignment of the $I G$ value is based on which materials are found in the study watershed. Throughout a simplification of the geological map (Fig. 3), we divided the watershed area into three zones, basing on lithological characteristics. For about $15 \%$ of the whole watershed area, alluvial covering is present and $I G$ is 5 . For about $25 \%$ of the whole watershed area, terrigenous rocks are present (in this group we include formations with prevalent marly/clay composition: Bisciaro, Scaglia Cinerea, Scaglia Variegata, and Marne a Fucoidi) and $I G$ is 3 . For about $60 \%$ of the whole area calcareous rocks are present (in this group we include formations with prevalent carbonate composition: Scaglia Rossa, Scaglia Bianca, Maiolica, and Calcari Diasprigni) and $I G=1$.

Let $p_{i}$ the percentage of the basin constitute by each lithotype in which the watershed has been subdivided, the general expressions to evaluate the mobilizable volume are:

$V=45 \cdot A^{0.9} \cdot I_{C}^{1.5} \cdot \sum_{i=1}^{3} I G_{i} \cdot p_{i}$

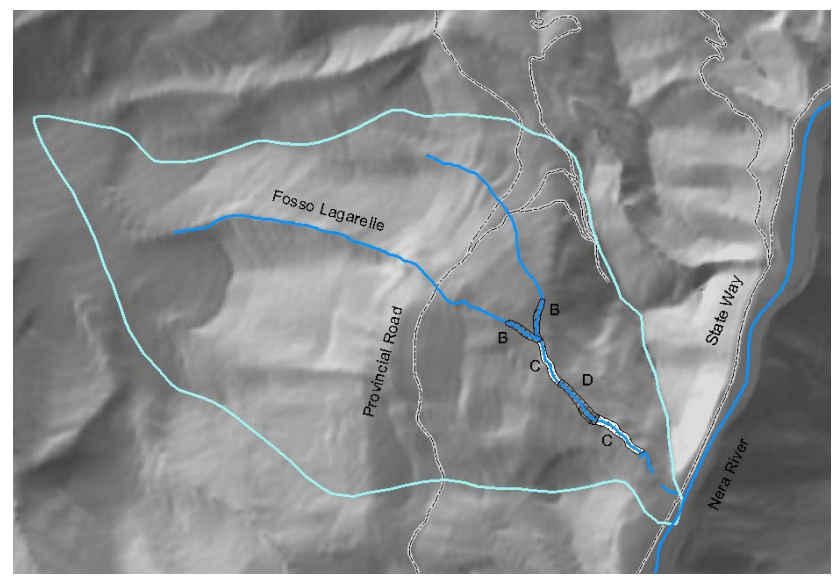

Fig. 10. Subdivision of the Lagarelle creek in homogeneous sectors, based on geomorphologic method.

$V=70 \cdot A \cdot I_{C}^{1.28} \cdot \sum_{i=1}^{3} I G_{i} \cdot p_{i}$

The results obtained from the application of the empirical relations, given by Eqs. (5) and (6) are shown in Table 4, with the one supplied from the gemorphologic approach.

\section{Discussion}

The volumes of the debris flows occurred in the Lagarelle Creek, evaluated on the basis of local witness, have been compared with those obtained by the geomorphologic approach and by empirical formulas. The geomorphologic approach leads to an overestimation of the volumes involved in potential debris flows with respect to those estimated from the eyewitnesses reports. This could be explained by two important factors. The first one refers to the fact that the method considers all the sources of sediment as simultaneously active. The second depends on the hypothesis that release and redeposit processes along the torrential stream are excluded, assuming that all the transported material reaches the terminal part of the channel. A more probable situation might imply the most important debris yields to come only from the downstream part of the creek riverbed, where the erosive energy of the moving mass grows higher. In fact, if we consider just the contribution of the terminal sectors (approximately a third part of the channel), the predictions are closer to the estimated volume data. Moreover, due to the morphometric characters of this part of the channel (limited average slopes), it is presumable that a significant percentage of the material is redeposited before reaching the end of the fan. Therefore, the volume estimated on indirect measures of the material arrived to the final part of the basin, constitute a fraction of those actually mobilized. This is extendible to such type of phenomena. In fact, also according to studies carried out on Swiss debris flows (Rickenmann and Zimmermann, 1993) it has been found out that the debris volumes measured in correspondence of the fan would correspond to 
Table 4. Summary of the results from the application of the predictive methods.

\begin{tabular}{cccc}
\hline & $\begin{array}{c}\text { Geomorphologic } \\
\text { approach }\end{array}$ & $\begin{array}{c}\text { Empirical relation } \\
\text { (D'Agostino et al., 1996) }\end{array}$ & $\begin{array}{c}\text { Empirical relation } \\
\text { (D'Agostino and Marchi, 2001) }\end{array}$ \\
\hline Results & $8400 \mathrm{~m}^{3}$ & $37630 \mathrm{~m}^{3}$ & $29800 \mathrm{~m}^{3}$ \\
\hline
\end{tabular}

approximately the $80-90 \%$ of the total volume moved in the river basin.

It is widely recognized that the empirical formulas hardly fit a physical environment that considerably differs from the ones they have been calibrated on.

Examining the watersheds' features for the elaboration of D'Agostino and D'Agostino and Marchi equations, we found out a first common characteristic regarding the dimensions of the considered basin (limited extensions). A further shared aspect was the geolithological-index table containing lithologic classes among which the Appenine formations can be classified. Nevertheless, while examining the debris flows data set used by the authors for the calibration of the empirical relations applied in the present work, we realized resulting overestimations would come out. In fact, the data set is made up of records of the debris flow greatest volumes occurred in the eastern alpine area. These records show higher volumes (up to $70000 \mathrm{~m}^{3} \mathrm{~km}^{-2}$ ) than those estimated in the two major events that occurred in the Lagarelle Creek watershed.

As to the transferability of the Geolithological Index $(I G)$ table, several statements are to be made. On one hand, the table provides a very ready to use classification tool, with lithotypes which are also found in the study basin. On the other, it allows no fully exhaustive description, due to a different physical environment. For example, we retain that the alluvial deposits of the Appennine area are not easily expressible with only one parameter because of their different conditions of density and grain-size. Very dense alluvial deposits that can't be easily mobilizable are frequent. Therefore, the possibility to consider also the characteristics of the debris deposits (in terms of homogeneity, grain-size distribution and state of density) seems to be important for the lithologic classification of the material involved in the Appennine areas.

\section{Conclusions}

This paper has examined the hydrographical watershed of the Lagarelle Creek in the eastern Umbria region. Within the basin, the zone with high hazard of debris flow is located in the terminal part of the torrential stream, as pointed out by the landslide inventory map produce with the "Piano stralcio per l'Assetto Idrogeologico" (Regione dell'Umbria, C.N.R. I.R.P.I., 1996). Any possible mobilization of the alluvial clastic material would compromise both a significant part of the town that has developed occupying all the central band of the gullies, and the underneath state way "S.S. n. 209
Valnerina", the only important interregional infrastructure of eastern Umbria.

At first, the geological and morphological characteristics of the basin have been illustrated; this is necessary to recognize the presence and the entity of the material, which could be involved in a debris flow. Then, on the basis of the collected information, a quantitative evaluation of the mobilizable volumes has been supplied for last century's most relevant events.

Hence, predictive methods have been used, such as the geomorphologic approach by Hungr and the empirical relations calibrated on events occurred in the eastern alpine arc, to attempt an assessment of the potential available debris within the basin. It has been observed that both methodologies provide overestimations of the mobilizable volumes along the Lagarelle Creek. In fact, in both cases the debris potential recognized within the basin is higher than that actually mobilized by the two major events of the last century. Particularly, in the case of the empirical approach, the estimations are greater. Possible justifications to this behaviour have been discussed, mainly referring to their difficult adaptability to a very different physical environment from those in which they have been calibrated on. To the contrary, the geomorphologic method, even though it supplied an overestimation of the effectively mobilized volumes, it is able to provide an approximated forecast closer to the estimated values from the witnesses reports.

However, from the statistical point of view the analyzed events are not sufficient to entrust one of the two predictive methods with a higher level of adaptability in the study watershed. Nevertheless such cases (as reported by the eyewitnesses) give a clear idea of the events entity and are necessary for a direct comparison with the estimations supplied by the various approaches.

The study has therefore shown the urgent need for a method to forecast the mobilizable volumes in debris flow events. They might remarkably reduce the hazard linked to such events.

Edited by: G. B. Crosta

Reviewed by: two referees

\section{References}

Bianco, G. and Franzi, L.: Estimation of debris flow volumes from storm events, in: Debris Flow Mitigation: Mechanics, Prediction and Assessment, edited by: Wieczoreck, G. F. and Naeser, N. D., Balkema, Rotterdam, 441-448, 2000. 
Bottino, G. and Crivellari, R: Analisi delle colate detritiche connesse con l'evento alluvionale del 5-6 Novembre 1994 nell'anfiteatro morenico di Ivrea, Proceedings on Rischio Idrogeologico, Opere di Difesa ed Uso del Territorio nel Canavese, Ivrea (in Italian), 1996.

Brochot, S., Marchi, L., and Lang, M.: L'estimation des volumes des laves torrentielles: methodes disponibles et application au torrent du Poucet (Savoie), Bulletin of Engineering Geology and the Environment, 61, 4, 389-402, 2002.

D'Agostino, V., Cerato, M., and Coali, R.: Il trasporto solido di eventi estremi nei torrenti del Trentino orientale, International Symposium Interpraevent, Garmisch-Partenkirchen, Germany, 1, 377-386 (in Italian), 1996

D'Agostino, V. and Marchi, L.: Debris flow magnitude in the Eastern Italian Alps: data collection and analysis, Phys. Chem. Earth. C., 26, 9, 657-663, 2001.

Guzzetti, F. and Cardinali, M.: Carta inventario dei fenomeni franosi della regione Umbria e aree limitrofe. G.N.D.C.I., pub. n. 204, scala 1:100 000, 1989.

Hungr, O., Morgan, G. C., and Kellerhals, R.: Quantitative analysis of debris torrent hazard for design of remedial measures, Canadian Geotechnical Journal, 21, 4, 663-677, 1984.
Kronfeller-Kraus, G.: Quantitative estimation of torrent erosion, in: International Symposium on Erosion, Debris flow and Disaster Prevention, Tsukuba, Japan, 107-110, 1985.

Marchi, L. and Tecca, P. R.: Magnitudo delle colate detritiche nelle Alpi Orientali Italiane, GEAM, 33, 2-3, 79-86, 1996.

Regione dell'Umbria - C.N.R. I.R.P.I.: Piano stralcio per l'Assetto Idrogeologico: siti censiti ai sensi della Legge 267/98, sito di Piedipaterno, Perugia (in Italian), 1996.

Regione dell'Umbria: Carta geologica dell'Umbria, Vallo di Nera, sezione n. 336030, Progetto carta geologica della Valnerina L.R. n. 25/1989, Perugia, 1995.

Rickenmann, D.: Estimation des laves torrentielles, IAS - Ingenieurs et Architectes Suisses, 19, 386-392, 1997.

Rickenmann, D. and Zimmermann, M.: The 1987 debris flow in Swizerland documentation and analysis, Geomorphology, 8, 175-189, 1993.

Takei, A.: Interdependence of sediment budget between individual torrents and a river-system, International Symposium Interpraevent, Villach, Austria, 35-48, 1984. 